\title{
Effects of Leadership Styles on Employee Performance: A Case Study of Turnall Holdings LTD, Harare
}

\section{Masevo Beauty and Osaro Aigbogun}

To Link this Article: http://dx.doi.org/10.6007/IJARBSS/v12-i1/12037

DOI:10.6007/IJARBSS/v12-i1/12037

Received: 03 November 2021, Revised: 05 December 2021, Accepted: 24 December 2021

Published Online: 08 January 2022

In-Text Citation: (Beauty \& Aigbogun, 2022)

To Cite this Article: Beauty, M., \& Aigbogun, O. (2022). Effects of Leadership Styles on Employee Performance: A Case Study of Turnall Holdings LTD, Harare. International Journal of Academic Research in Business and Social Sciences, 12(1), 289-305.

Copyright: @ 2022 The Author(s)

Published by Human Resource Management Academic Research Society (www.hrmars.com)

This article is published under the Creative Commons Attribution (CC BY 4.0) license. Anyone may reproduce, distribute, translate and create derivative works of this article (for both commercial and non0-commercial purposes), subject to full attribution to the original publication and authors. The full terms of this license may be seen at: http://creativecommons.org/licences/by/4.0/legalcode

Vol. 12, No. 1, 2022, Pg. $290-305$

Full Terms \& Conditions of access and use can be found at http://hrmars.com/index.php/pages/detail/publication-ethics 


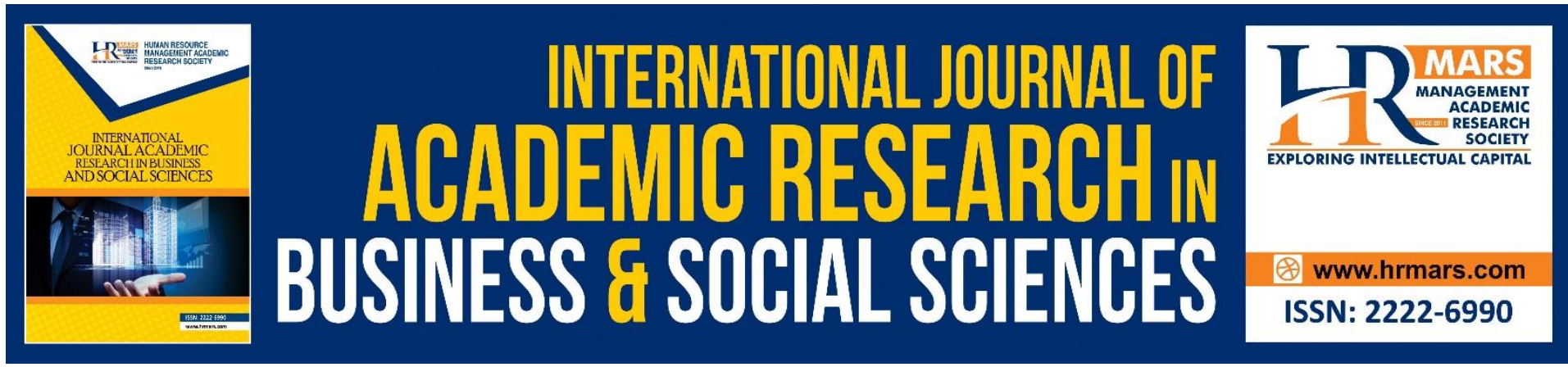

\title{
Effects of Leadership Styles on Employee Performance: A Case Study of Turnall Holdings LTD, Harare
}

\author{
Masevo Beauty ${ }^{1}$ and Dr. Osaro Aigbogun ${ }^{2}$ \\ ${ }^{1}$ DBA Researcher, Binary University of Management \& Entrepreneurship, Malaysia and \\ ${ }^{2}$ Senior Lecturer, Binary University of Management \& Entrepreneurship
}

\begin{abstract}
This article presents the results of a study that was undertaken to examine the impact of styles of leadership on employees' performance, mainly the impact of transformational, transactional and laissez -faire leadership styles. In addition, especially, during rapid Covid-19 pandemic, leadership skills that effectively maintain organizational goals and objectives at the same time managing teams effectively is the key for organizational sustainability. Thus, crucial issues that impact leadership aiming to implement policies by World Health Organization (WHO) in an effort to curb contagion to employees are discussed. Statistical population of the study consists of 255 employees. A sample size of 156 was drawn from Turnall Holdings using a stratified random sampling technique. A quantitative approach, descriptive survey research design and a structured questionnaire which consists of close-ended questions were used for this study. The questionnaire was analyzed using Statistical Package for Social Sciences (SPSS) version 23.0. The leadership styles were measured through the Multi-factor Leadership Questionnaire. Employee performance was measured using Yousef (2000) scale. Regression, descriptive, demographic analysis and reliability test, (Cronbach's Alpha) were presented. For data analysis, descriptive and inferential techniques were used. Regression coefficient was utilized to assess the influence of styles of leadership on the performance of employees. Results exhibited that transformational and laissez-faire styles significantly positively impact employee performance. Whilst, transactional leadership is found to have a negative impact. Hence, to achieve desired upsurge performance this study commends that leader should exert more transformational followed by laissez-faire attributes and possibly shun transactional style since it diminishes employee performance. Study findings can benefit leaders as they could recognize and adopt the most appropriate styles and skills of leadership to be executed in order to attain maximum employee performance during and post Covid-19 pandemic.
\end{abstract}

Keywords: Leadership, Laissez-faire Leadership Style, Transactional Leadership Style, Transformational Leadership style.

\section{Introduction}

Styles of leadership implemented by the leader in an organization significantly influence the relationship between the employee and the leader and also the efficiency of employees' 
performance (Jeremy et al., 2012). Hence, this reveals that the achievements or failure of an organization is dependent on implemented leadership attributes. Besides, Lewis \& Gilman (2013) postulate that appropriate leadership styles raise employee performance, thereby, increasing the productivity of employees in various segments of economics. Rist (2020) added that prior covid-19, leaders concentrated mainly on strategic issues whereas, today on account of the existing pandemic, challenges are also inseparably associated to employees they lead. Hence, leaders during crisis should practice styles that demonstrate diligent care and empathy to employees in such times of uncertainty. Thus, this paper reports on the findings of study that investigated leadership styles and their influence on employee performance. To accomplish this aim, the study sought to ascertain styles of leadership that are suitable in the context of Turnall Holdings Ltd in Zimbabwe.

A substantial number of scholars have studied and presented evidence about different styles of leadership that any particular leader can adopt in order to influence 1 employees to seek the highest level of commitment (Oladipo et al., 2016; Bogler, 2015). Consequently, these researches show the importance of leadership styles that stimulate employees to willingly exert effort to meet the organization's predetermined goals and objectives. Stimulation of employees is essential because human beings are motivated to join an organization not necessarily that they want to meet organizational goals but because they intend to meet leadership traits that are capable of influencing employees to accomplish or transcend organizational set goals. In support of the notion, Akpala (1998) added that lack of motivation, job dissatisfaction, and negative attitude at work are some of the factors that may cause a decline in employee efficiency which may lead to a reduction in company profits. Like manner, (Wolor et al., 2020) further states that due to current pandemic cultivating the development also supervision of subordinates remotely has become a great challenge to leadership. Therefore, the researcher made a thoughtful effort to identify the most appropriate styles of leadership that could encourage employees to become competent and committed to effectively escalating expected performance at Turnall Holdings. It was considered prudent to engage a quantitative method for this study since the technique can fulfil the objective of the study by measuring statistically the relationship that exists between the variables.

Study findings can benefit leaders as they come to appreciate the most appropriate style of leadership to be executed in order to attain maximum employee performance. Thus, leadership development programs should be established and also some training and seminars can be helpful in escalating awareness among supervisors and leaders: thereby, the performance of workers improves. For this study, transaction style had a negative impact on employee performance; hence, this suggests that neither extrinsic nor intrinsic rewards are motivating employees. Therefore, the leadership style should be shunned and (transformational, laissez-faire styles) that demonstrated higher performance outcomes should be encouraged. Conversely, current literature showed that amid leadership styles and performance outcomes there exists a substantial positive relationship.

Furthermore, study findings concur with a transformational theory which ascertains that leaders' attributes of inducing others to perform positively involve inspirational motivation, encouragement of innovative ideas, and visionary leading (Murphy \& Drodge, 2004).

The existing literature gap concerning styles of leadership and performance of employees is addressed in this study. The subject area is poorly researched in undeveloped countries; few researches have been published in developing countries particularly in the 
manufacturing industries in Zimbabwe (Tsigu \& Rao, 2015). Mwenje \& Mwenje (2017) concur those similar studies undertaken in Zimbabwe focused on the retail sector leaving out other industries. Given that, from the reviewed literature no study was conducted in the manufacturing industry in Zimbabwe that examines leadership effects on employee performance. Therefore, this is evident that the results of the current study could contribute to the body of knowledge.

Besides, Turnall Holdings leaders together with other managerial key personnel in the manufacturing organizations especially in Zimbabwe could greatly benefit from the current study findings, as they could recognize and appreciate leadership style to employ in relevant situation like this pandemic era. Moreover, the results could be of great importance to company policy-makers as they structure policies which relate to employee performance and leadership styles during this current pandemic. Other beneficiaries of the study will include academicians and students since the study contributes to the present literature, they can further digest the consequence and importance of different styles of leadership that can enhance employee performance. Consequently, the study findings will be useful for future studies by other researchers as they can be further used for other findings that can motivate changes to the benefit of companies.

\section{Literature Review Leadership}

The strong determination shown by a leader to ensure all individuals in a group are inspired and encouraged to exert maximum effort to attain organizational set objectives and goals is known as leadership (Northhouse, 2016). Tactics displayed by a leader as a means of providing direction, planning, implementing and motivating the team are recognized as leadership responsibilities. Consequently, what has been suggested above indicates that the key component of a successful organization is leadership. Besides, leadership encompasses communicating and guiding team members, empowering, encouraging and inspiring them to earnestly work towards accomplishing organizational desired set goals.

For employees to provide their best for the success of an organization, it calls for leadership qualities that strategically focusses and implements behavioural tactics that build employee commitment (Chowdhury, 2014). Further indicated that it is widely agreed that effective leadership is not easy to come by, it is a multifaceted and is known to be dependent on particular elements such as, difficulty of tasks, extend at which the leader gives authority and the maturity and competence of employees. However, Chen \& Sriphorn added that complexity of leadership has been intensified by the current pandemic. Hence, the need for leaders who are responsible, innovative and determined to confront unanticipated devastating changes and pursue attaining positive effect in relation to productivity.

The complexity and indefinability of the word leadership may be the reason which makes it difficult to come up with a single definition for the concept. Lassey (1976) noted the complexity of the phenomenon and proclaims that there could be no single meaning of leadership that may cover all circumstances. To reconcile the discrepancies noted on definitions of leadership the Chemers (1997) came up with an umbrella description which is acceptable to the majority of researchers and theorists. Chemers present a definition that defines leadership as "a process of influence whereby, an individual can solicit full support from subordinates to meet the set goals or defined duties". Similarly, Conger \& Kanungo, (1998) defined leadership as "people who create direction for team members and gain the commitment of the members and finally motivate them to attain the intended 
outcome".

However, considering all the above definitions of prior and current literature about leadership, the provided meanings varied, but one common facet noted is that all leaders strive to influence employees to meet targets, set goals and objectives of the organization which in turn enhance productivity. Transformational, laissez-faire and transactional leadership styles are expounded in the succeeding section.

\section{Styles of Leadership}

\section{Transformational leadership Style}

Transformational leaders are characterized by enthusiasm, energy and passion. They aim at transforming subordinates' capabilities, skills, beliefs and values. Transformational leaders always make an effort to ensure that followers are motivated through influencing their assumptions and attitudes towards work. Caciope (1997) asserts that leaders who apply transformational style motivate and encourage subordinates to accomplish more than their expectations through communicating a clear convincing vision to them. Transformational leaders are known to be trustworthy and honest; they ensure that the vision of the organization is shared; goals are clearly set and well communicated to employees (Bass and Bass, 2009). In this manner, employees get inspired to willingly offer their services beyond set limits. Apart from working towards skill and capability enhancement of followers, transformational style is characterized by leaders who align employees' goals with organizational goals. Moreover, Cho \& Dansereau (2010) advocated that leader who apply transformational attributes instigate team spirit, intellectual development, enthusiasm and confidence among subordinates. In so doing, subordinates are prompted to remain focused on accomplishing organizational set goals together with their collective wellbeing. Nevertheless, Emmeett, Schrah, Schrimper \& Wood postulates that under the pressure of Covid-19, leaders need to intensify knowledge on how to build and employ effective styles of leadership that can enhance performance. In light of the above, it shows that outdated practices and attributes pre Covid-19 should be improved.

\section{Transactional Leadership Style}

Transactional leaders believe in close supervision, identifying mistakes and application of corrective measures to rectify errors (Obiwuru, 2011). Additionally, Shah \& Kamal (2015) pointed out that leaders who employ a transactional style prefer the status quo, no diversification, they strictly adhere to stipulated parameters in an effort to attain maximum performance from subordinates. Transactional style of leadership is defined and expounded by Bass (1997) as a style of leadership that is characterized by authority and conservative administrative powers. The transaction leadership style from Bass \& Aolivo (1990) point of view is a reciprocity form of deal that involves leaders and followers exchanging services. Burns (1978) echoed the same sentiments that, "leaders approach followers with an eye to exchanging one thing for another". In the same vein, Bass \& Avolio (1990) added that transactional leaders interchange benefits and rewards to subordinates provided the assigned task is completed, and the agreed-upon targets are fulfilled successfully. Bass and Riggio (2006) added that "transactional leaders either deny to offer rewards if targeted production is not met, on the other hand, they offer monetary rewards for high productivity". With this type of style there is a condition to be fulfilled, that is, individual needs and aspirations are fulfilled provided the leader's expectations and requirements are met satisfactorily. In actual fact, many researchers understand transactional leadership style as 
punishment for perceived wrong behaviour and reward for observed respectable behaviours (Fredendall, Laohavichien, \& Cantrell, 2009). This shows that in most cases subordinates' performance is limited to the reward promised, hence, their performance does not surpass the anticipated reward.

\section{Laissez - faire style of Leadership}

Under the laissez-faire style of leadership, power and authority are left to subordinates to do all they please. They are the ones to determine organizational objectives and goals. Managers will not provide any kind of assistance or direction; employees are left to freely make a decision (Richard et al., 2009). This means leaders stand aloof, do not interfere with subordinates. For that reason, some scholars call such leadership style a destructive style (Skogstad et al., 2007) whilst others perceive this style to be a no-leadership style (Aydin et al. 2013; Bass, 1990; Lam \& O'Higgins, 2012). Not only the decision-making responsibility is left to the subordinates, but also leaders tend to neglect other issues such as care of the employee's needs, failure of leaders to provide feedback and some delays are experienced when quick decisions are needed (Bass \& Riggio, 2006). In addition, Ololube (2013) postulates that the laissez-faire leadership style happens when leaders lack control over their subordinates. This situation denotes that employee are left with the freedom to do what they desire to do at the time they want to do it without any restriction from management. Goodnight (2011) suggested that when all power to decide to work-related issues is given to subordinates, in some certain situations and industry this style can provide a positive impact on employee performance. Furthermore, he mentioned that when freedom to make the decision is allowed to group members like professors, doctors', engineers' etcetera, laissezfaire leadership style can be recognized to be the best style. Affirmatively, Mawoli, Mohammed and Sarkin-Daji (2017) in their findings established that laissez-faire leadership style positively influences staff performance at Federal Medical Centre

\section{Virtual Leadership}

Management of individuals or team members who are located in different remote locations is known as virtual leadership (Cascio, 2000). Further asserts that both traditional and virtual leadership focus on building teams, motivating employees, attaining of goals and good performance. However, Powell \& Piccoli, (2004) pointed out that unlike traditional leadership, virtual leadership to function properly it is critical to have effectual technology for instance internet networks that are reliable. Mehtab, Rehman, Ishfaq and Jamil (2017) in their study established that good communication is key to the success of virtual teams. Gazor, (2012) postulates that virtual teams are exerting much effort to improve performance and to apply resources and talent efficiently. Moreover, claim that there are some challenges as well as opportunities associated with virtual work. To resolve challenges (Lilian, 2014) mentioned that E-leaders need to transform such difficult encounters into opportunities.

\section{Methodology}

\section{Research Design}

For this study quantitative technique was used. It was deemed appropriate since most importantly, it can also measure numerically the relationship that exists between variables, which is the objective of the present study. 


\section{Study Population}

The population targeted for this study was comprised of 255 permanent staff members of Turnall Holdings based in Harare. These were supervisors and team leaders from various units of the organization.

\section{Sampling Technique and Sample Size}

The study adopted probability sampling method. The technique was deemed appropriate when selecting a representative sample from the corresponding departments. Each unit was adapted as a stratum at which sample group members were drawn. Subsequently, for this study, the researcher picked in a random manner individual participant of the study from varied departments within the organization.

This method was selected because it ensures unbiased representation from all units of the population, thereby, reducing sampling errors and curtail bias and at the same time increasing efficiency (Edmonds \& Kennedy, 2017). A sample size involving 156 research participants was considered adequate for this study. More so, the sample size enabled satisfactory gathering of diverse data thereby, increasing reliability of the study findings (Faul et al., 2014).

\section{Measurement of Variables}

A research questionnaire cantered on five-point likert scale was utilized that is, $5=$ strongly agree; 4=agree;

3=undecided; 2=disagree; 1=strongly disagree. The Multi-factor Leadership Questionnaire (MLQ) by Avolio \& Bass (1995) was adopted and some modifications were done to suit this study. Employee performance was the second variable measured and Yousef, (2000) scale was used.

\section{Data Collection and Analysis}

Data was gathered through a questionnaire. It was handed to every prospective respondent as this promoted greater response. Out of 156 questionnaires handed to participants, 102 were returned. Hence, out of the 102 returned questionnaires, three of them were not fully completed. Questionnaires from 99 participants were fully completed, corresponding to 63.38\% responding rate. Statistical Package for Social Science (SPSS) version 23.00 was used to analyse data for this study.

\section{Validity and Reliability}

To assess content validity five experts were identified and were requested to scrutinize the appropriateness and adequacy of the instrument. The Cronbach's alpha coefficient was employed to examine the reliability of the questionnaire, the results were 0.849 which is inferred as good according to (Shuttleworth, 2015) for it is well above the minimum conventional level cut-off point 0.700 . Results and findings are deliberated in the following section. 


\section{Results and Discussion}

Table 4.1: Demographic info

\begin{tabular}{|c|c|c|c|}
\hline & Items & Frequency & $\%$ \\
\hline \multirow{2}{*}{$\begin{array}{l}\text { Gender of } \\
\text { respondents }\end{array}$} & Male & 53 & 53.5 \\
\hline & Female & 49 & 46.5 \\
\hline \multirow{6}{*}{ Age distribution } & $<20$ years & 1 & 1.0 \\
\hline & $21-30$ years & 39 & 40.6 \\
\hline & $31-40$ years & 30 & 31.3 \\
\hline & $41-50$ years & 14 & 14.6 \\
\hline & $51-60$ years & 12 & 12.5 \\
\hline & $>61$ years & 0 & 0 \\
\hline \multirow{4}{*}{ Educational Level } & Diploma & 22 & 26.8 \\
\hline & Master's Degree & 26 & 31.7 \\
\hline & Undergraduate & 22 & 26.8 \\
\hline & Doctorate & 12 & 14.7 \\
\hline \multirow{5}{*}{ Departments } & Production and Engineering & 40 & 43.5 \\
\hline & Marketing & 32 & 34.8 \\
\hline & Human Resources & 7 & 7.6 \\
\hline & Purchasing & 7 & 7.6 \\
\hline & Finance and Administration & 6 & 6.5 \\
\hline \multirow{6}{*}{ Years of Experience } & $1-5$ years & 36 & 39.6 \\
\hline & $6-10$ years & 39 & 42.9 \\
\hline & $11-15$ years & 8 & 8.8 \\
\hline & $16-20$ years & 4 & 4.4 \\
\hline & $21-25$ years & 3 & 3.3 \\
\hline & $>26$ years & 1 & 1.1 \\
\hline
\end{tabular}

With regard to gender, table 4.1 displayed that out of 99 respondents, 46 were females and 53 were males. This is to say, fewer participants were female with $46.5 \%$ whilst more were male at 53.5\%. Therefore, this reflects gender balance. Almost an equal number of men and women were employed in supervisory positions. This reflected that in terms of gender, male and female employees at Turnall Holdings were fairly represented.

Considering the age range categories, the age range of 21-31 years had the highest percentage of respondents 40.6 , followed by the age range of $32-42$, scoring $31.3 \%$. This suggests that, overall, the company had more young people and middle-aged personnel. Hence, when robust leadership styles are adopted, the company will sustain a competitive advantage as vibrant young people retention within the company will be inevitable. Results exhibited that the least level of education is a diploma, this depicts that Turnall had educated competent staff who are capable of providing a good assessment of their performance as well as the leadership style of their managers.

Lastly, the results showed that high representation is displayed in the production department $43.5 \%$, this could be due to the fact that Turnal Holdings is an entity that focuses solely on the manufacturing of building materials and asbestos pipes. Hence, the majority of workers are assumed to be in the production sector. The majority of employees their years of service range is between $6-10$ years with (41.3\%). This inevitably depicts that the majority of responses were from staff who are acclimatized to the organization. It is known that the period of service is a very good determinant of the quality of responses from respondents 
towards leadership styles and employee performance factors. Presented in the following section are tables of descriptive statistics.

Table 4.2 Transactional Leadership

\begin{tabular}{|l|l|l|l|l|l|l|}
\hline \multirow{2}{*}{ STATEMENT } & \multicolumn{2}{l|}{ N } & \multicolumn{3}{l|}{} \\
\cline { 2 - 6 } & Valid & Missing & Min & Max & Mean & Std. Dev \\
\hline $\begin{array}{l}\text { I am constantly reminded of what I would } \\
\text { receive if I do what is expected. }\end{array}$ & 99 & 3 & 1 & 5 & 3.68 & .879 \\
\hline $\begin{array}{l}\text { When mistakes are made disciplinary } \\
\text { action is instituted. }\end{array}$ & 99 & 3 & 1 & 5 & 3.95 & .629 \\
\hline $\begin{array}{l}\text { My supervisor pays close attention to } \\
\text { anomalies that may arise. }\end{array}$ & 99 & 3 & 1 & 5 & 4.00 & .495 \\
\hline $\begin{array}{l}\text { I get rewarded for exceptional } \\
\text { performance. }\end{array}$ & 99 & 3 & 1 & 5 & 3.69 & 1.046 \\
\hline $\begin{array}{l}\text { My supervisor closely checks for } \\
\text { nonconformity and attend to it. }\end{array}$ & 99 & 3 & 1 & 5 & 3.99 & .544 \\
\hline
\end{tabular}

All most all responses given from all the parameters of transaction leadership style are more than the average 3.5. Therefore, such results validate that respondent were inclined towards accepting that their supervisors at Turnall practice transactional leadership style at a greater extent.

Table 4.3 Laissez-faire leadership style

\begin{tabular}{|l|l|l|l|l|l|l|}
\hline \multicolumn{2}{|l|}{ Laissez-faire Leadership Style } & \multicolumn{4}{l|}{} \\
\hline \multirow{2}{*}{\begin{tabular}{l} 
STATEMENT \\
\cline { 2 - 7 }
\end{tabular}} & Valid & Missing & Min & Max & Mean & Std. Dev \\
\hline $\begin{array}{l}\text { My supervisor stays out of the way as I do } \\
\text { my work }\end{array}$ & 99 & 3 & 2 & 5 & 3.04 & 1.029 \\
\hline $\begin{array}{l}\text { I have freedom to make decisions and } \\
\text { implement them }\end{array}$ & 99 & 3 & 1 & 5 & 2.85 & 1.044 \\
\hline $\begin{array}{l}\text { I am allowed to pursue organizational } \\
\text { objectives and make implementation }\end{array}$ & 99 & 3 & 1 & 5 & 2.83 & 1.060 \\
\hline $\begin{array}{l}\text { My supervisor gives me complete } \\
\text { freedom to solve problems on my own }\end{array}$ & 99 & 3 & 1 & 5 & 2.67 & 1.000 \\
\hline
\end{tabular}

Categories of the mean range displayed in table 4.3 above is below the average (3.50), thereby indicating vividly that respondents agree at moderate extend that laissez-faire style of leadership influence performance of employees. 
Table 4.4 Transformational Leadership

\begin{tabular}{|c|c|c|c|c|c|c|}
\hline \multirow[b]{2}{*}{ STATEMENT } & \multicolumn{2}{|l|}{$\mathbf{N}$} & \multirow[b]{2}{*}{ Min } & \multirow[b]{2}{*}{ Max } & \multirow[b]{2}{*}{ Mean } & \multirow[b]{2}{*}{$\begin{array}{l}\text { Std. } \\
\text { Dev }\end{array}$} \\
\hline & Valid & Missing & & & & \\
\hline I prepare a work plan at alltimes & 99 & 4 & 2 & 5 & 3.97 & .564 \\
\hline I always meet set targets & 99 & 3 & 2 & 5 & 3.87 & .649 \\
\hline I am always motivated to work & 99 & 3 & 1 & 5 & 3.69 & .853 \\
\hline $\begin{array}{l}\text { I diligently execute duties as per } \\
\text { schedule }\end{array}$ & 99 & 3 & 3 & 5 & 4.07 & .327 \\
\hline $\begin{array}{l}\text { When executing daily duties, I } \\
\text { collaborate with others }\end{array}$ & 99 & 3 & 1 & 5 & 4.09 & .517 \\
\hline
\end{tabular}

6

\begin{tabular}{|l|l|l|l|l|l|l|}
\hline $\begin{array}{l}\text { Resources are diligently utilized so as to } \\
\text { minimize wastage }\end{array}$ & 99 & 3 & 2 & 5 & 4.04 & .472 \\
\hline $\begin{array}{l}\text { I evaluate quality of my work after } \\
\text { executing }\end{array}$ & 99 & 3 & 3 & 5 & 4.13 & .368 \\
\hline $\begin{array}{l}\text { Standard on my work assignment is } \\
\text { always met }\end{array}$ & 99 & 3 & 2 & 5 & 4.01 & .484 \\
\hline $\begin{array}{l}\text { I do good job in terms of quantity and } \\
\text { quality }\end{array}$ & 99 & 3 & 2 & 5 & 4.13 & .420 \\
\hline I am very punctual at work & 99 & 3 & 3 & 5 & 4.15 & .437 \\
\hline
\end{tabular}

As observed from table 4.4 the study findings show that respondents strongly agree to a greater extent that transformational leadership style significantly positively impact employee performance. This is evidenced by categories of mean range which was above average (3.50).

Table 4.5 Employee Performance

\begin{tabular}{|l|l|l|l|l|l|l|}
\hline STATEMENT & Valid & Missing & Min & Max & Mean & $\begin{array}{l}\text { Std. } \\
\text { Dev }\end{array}$ \\
\hline $\begin{array}{l}\text { The vision and mission are communicated } \\
\text { to employees by leadership }\end{array}$ & 99 & 3 & 1 & 5 & 3.96 & .552 \\
\hline $\begin{array}{l}\text { I understand the vision of the organization } \\
\text { very well }\end{array}$ & 99 & 3 & 2 & 5 & 4.01 & .416 \\
\hline $\begin{array}{l}\text { I acknowledge and share the leaders long } \\
\text { term vision }\end{array}$ & 99 & 3 & 2 & 5 & 3.95 & .503 \\
\hline $\begin{array}{l}\text { I accept the role of leaders in the } \\
\text { organization }\end{array}$ & 99 & 5 & 2 & 5 & 4.02 & .433 \\
\hline $\begin{array}{l}\text { High performance expectancy is always } \\
\text { communicated by leadership }\end{array}$ & 99 & 4 & 2 & 5 & 4.06 & .450 \\
\hline $\begin{array}{l}\text { I am always motivated to view things from } \\
\text { different perspective }\end{array}$ & 99 & 3 & 2 & 5 & 4.01 & .505 \\
\hline $\begin{array}{l}\text { My supervisor shows great determination } \\
\text { in achieving set goals }\end{array}$ & 99 & 3 & 2 & 5 & 4.09 & .431 \\
\hline $\begin{array}{l}\text { I am comfortable when my supervisor is } \\
\text { around }\end{array}$ & 99 & 4 & 2 & 5 & 4.08 & .469 \\
\hline $\begin{array}{l}\text { Leadership identifies and satisfy the needs } \\
\text { of each employee }\end{array}$ & 99 & 3 & 1 & 5 & 3.79 & .718 \\
\hline $\begin{array}{l}\text { I have total confidence and trust in the } \\
\text { leadership }\end{array}$ & 99 & 3 & 1 & 5 & 3.78 & .736 \\
\hline I respect the leadership in my organization & 99 & 3 & 2 & 5 & 4.04 & .472 \\
\hline
\end{tabular}


Presented mean range category from $3.69-4.15$ indicated in table 4.5 confirms that respondents strongly agree that leadership styles influence performance of employees.

Table 4.6 Regression Coefficients

\begin{tabular}{|c|c|c|c|c|c|c|}
\hline \multirow{2}{*}{\multicolumn{2}{|c|}{ Model }} & \multicolumn{2}{|c|}{$\begin{array}{l}\text { Unstandardized } \\
\text { Coefficients }\end{array}$} & \multirow{2}{*}{$\begin{array}{l}\text { Standardized } \\
\text { Coefficients } \\
\text { Beta }\end{array}$} & \multirow[t]{2}{*}{$\mathbf{t}$} & \multirow[t]{2}{*}{ Sig. } \\
\hline & & $B$ & Std. Error & & & \\
\hline \multirow[t]{4}{*}{1} & (Constant) & 1.913 & .317 & & 6.037 & .000 \\
\hline & Transactional & -.059 & .060 & -.105 & -.988 & .326 \\
\hline & Laissez-Faire & .068 & .028 & .211 & 2.462 & .016 \\
\hline & Transformational & .536 & .102 & .564 & 5.261 & .000 \\
\hline
\end{tabular}

a. Dependent Variable: Employeeperformance

The results in table 4.6 revealed that Laissez-faire and Transformational style of leadership significantly influence employee work performance at $p<0.05$. Whilst, transactional style results entails that the leadership style reduces performance of employees by $10.5 \%$. This finding is similar to the finding of Veliu, (2017) in a study conducted in Kosovo.

Table 4.7 Model Summary

\begin{tabular}{|l|l|l|l|l|}
\hline Model & $R$ & R Square & $\begin{array}{l}\text { AdjustedR } \\
\text { Square }\end{array}$ & $\begin{array}{l}\text { Std. Error of the } \\
\text { Estimate }\end{array}$ \\
\hline 1 & $.585^{\mathrm{a}}$ & .342 & .321 & .24045 \\
\hline
\end{tabular}

Results presented in the table above exhibits that the coefficient of determination (R squared) was 0.342 which indicates that $34.20 \%$ of the changes in the performance of the employees is explainedby the independent variables (transformational, transactional and Laissez-faire) while $65.80 \%$ of the variations in employee performance cannot be justified by the variables used in this study.

\section{Discussion}

The analysed quantitative data from respondents revealed employees' perceptions regarding their leaders' styles of leadership. Coefficient regression analysis indicated that both transformational and laissez-faire leadership styles positively predict employee performance except transactional leadership style which exhibited a negative influence on employees' performance.

In this case, the majority of respondents agreed that most of their leaders execute transformational attributes. This entails that leaders motivate, encourage and raise followers' spirits inspiring them to perform at the best of their abilities for the sake of organization success (Lussier \& Achua, 2007). On the other hand, employees are left to make decisions and implement as they see fit. Therefore, this shows that the team leaders and supervisors who execute both transformational and laissez-faire styles upsurge performance. This view is contrary to Bass et al (2012) who opined that transformational and transactional are effective approaches for attaining the organization's desired performance. Current study results revealed that transformational leadership style influences employee performance more than laissez-faire. This signifies that, the more the company leaders and managers exhibit transformational leadership attributes, the more the employees intensify performance.

The coefficients of the regression results displayed that the laissez-fare leadership style also had a positive effect on employee performance at Turnall Holdings. This confirms that the 
implementation of this style enhances the performance of employees. Other studies reviewed were contrary to this study's results. One example is a study carried within the local government setting in the United States of America by Muterera, (2012). The findings indicated that laissez-faire leadership style exerts a negative impact on employee performance. Similarly, research findings concurred with those conducted in Chile by Rejas et al., 2006).

On the other hand, current study transactional style results showed a negative impact on the performance of employees. This suggests that supervisors or leaders who implement corrective, contingent reward and management by exception traits retards employee performance and never attain higher performance.

\section{Summary of Findings}

Results of this study indicated that transformational leadership style had a significant positive impact on employee performance. For this study, the transformational style came out to be the best concerning influencing employee performance. Consequently, this entails that leaders who execute more transformational attributes accelerate the performance of followers more.

Findings on the transactional style of leadership denote a negative impact on employee performance, such results serve as evidence that employees are not motivated to intensify performance on the condition that rewards for exceptional performance are instituted. Thus, implementation of the style will decrease employee performance. On the other hand, the outcome portrays that employee perceive transactional leaders or managers to be non- effective. The laissez-faire style of leadership results displayed a positive influence on employee performance. This exhibits that managers and supervisors who practice this style upsurge employee performance. Affirmatively, Wong \& Giessner (2018) concurred that the laissez-faire style of leadership impact on employee performance is perceived as less in comparison with transformational style.

Overall, the outcome of the current study shows that the performance of employees is positively influenced by leadership styles (transformational and laissez-faire) except for the transactional style.

\section{Recommendation}

Adoption of the correct leadership style enables an organization to deal with the numerous daily challenges which firms yearn to handle in order to achieve competence, effectiveness and excellence in employee performance. Nevertheless, owing to the findings exhibited in this research, recommendations were made as follows: -

* Firstly, management in an organization must effectively engage all managers at different levels and sectors to adopt a transformational style of leadership when discharging their responsibilities.

Top management should ensure all managers or supervisors get some training and seminars to make sure they understand traits and the benefit of transformational leadership style to both employees and the organization.

* Secondly, the laissez-faire leadership style similarly had a positive influence on employee performance though it is less in comparison with the transformational style. Therefore, it is commended that the laissez-faire leadership style should be implemented by senior management especially in the manufacturing sector. Based on the results these two styles displayed a higher capability of increasing performance of employees. In support of this 
study's findings, Bass, (1985) pointed out that tremendous leaders are those leaders who execute both laissez-faire and transformational characteristics.

* Thirdly, due to the negative impact displayed by transactional leadership style it is therefore commended that the style should be shunned. Policies should be put in place that discourages the practice of this style. It is prudent that the organization should select the best approaches that will induce the optimal performance of workers. In this case, transformational and laissez-faire should be fully executed to attain anticipated performance in an organization.

Lastly, based on study findings, it is confidently proven that transformational followed by laissez-faire leadership styles transcends performance and these two have withstood the test of time. This entails that the ideal style of leadership to be practiced involves both transformational managerial capabilities together with those components of laissez-faire style. In that view, both styles are recommended for adoption to Turnall Holdings manufacturing setting without any reservations. Whilst, transactional leadership attributes should be cast-off, for the study established that the style dwindles employee performance. The performance of an employee is directly in proportionate with the effectiveness of a leader. Henceforth, current challenges at Turnall Holdings, consecutive drop in revenue, losses and insignificant profits can be effectively resolved if management uses the composition of transformational and laissez-faire styles and considers both styles to be the key managerial strategy.

\section{Further Studies}

For this study, only a single organization, that is, Turnall Holdings participated: therefore, as a matter of reducing the possibility of cultural biases, upcoming researchers may consider the inclusion of several other manufacturing organizations. For an expansive view, forthcoming researchers can work with a much bigger sample size involving different industries other than manufacturing industries, namely, banking, travel, hospitality and retailing services. Furthermore, studies to be carried in the future may involve the use of other different leadership styles, how they affect employee performance in other dissimilar industries and other countries in different economic environments.

More so, the model can be expanded to include employees: work outcome, for instance, turnover intentions, and work commitment. Besides, future researchers may consider the use of different research designs such as qualitative or mixed research methods since the results from such research methodology could provide additional in-depth perceptions of the respondents.

\section{Conclusion}

Given the research findings, transformational, and laissez-faire styles had a significant positive impact on the performance of employees. Transformational is noted to be more related and impactful as compared to the laissez-faire style. On the other hand, the transactional leadership style denoted a negative influence on performance of employees.

Furthermore, in respect of the study's main objective, it can be concluded that the performance of employees may be positively or negatively influenced depending on the leadership style employed. Study findings agree with Obiwuru et al. \& Jeremy et al. (2012) who pointed out that leadership styles had an impact on employee performance. Considering the implications and conclusion drawn it is vivid that all those in managerial positions could easily identify and deploy an effective style of leadership that addresses the knowledge gap 
that currently exists in the Zimbabwean manufacturing industry. Besides, policy-makers may be guided when constituting policies that enhance employee performance with regard to present Covid-19 pandemic.

\section{References}

Avolio, B. J., \& Bass, B. M. (1995). Individual consideration viewed at multiple levels of analysis: A multi-level framework for examining the diffusion of transformational leadership. The leadership quarterly, 6(2), 199-218.

Aydin, A., Sarier, Y., \& Uysal, S. (2013). The Effect of School Principals' Leadership Styles on Teachers' Organizational Commitment and Job Satisfaction. Educational sciences: Theory and practice, 13(2), 806-811.

Bass, B. M. (1995). Theory of transformational leadership redux. The leadership quarterly, 6(4), 463-478.

Bass, B. M. (1997). Does the transactional-transformational leadership paradigm transcend organizational and national boundaries'? American Psychologist 52, 130-139.

Bass, B. M., \& Bass, R. (2009). The Bass handbook of leadership: Theory, research, and managerial applications, Simon and Schuster.

Bass, B. M., \& Avolio, B. J. (1990). Transformational Leadership Development: Manual for the Multifactor Leadership Questionnaire. Palo Alto, CA: Consulting Psychologists Press.

Bass, B. M., Avolio, B. J., Jung, D. I., \& Berson, Y. (2012). Predicting unit performance by assessing transformational and transactional leadership Journal of Applied Psychology 88 207-218.

Bass, B. M., \& Riggio, R. E. (2006). Transformational leadership New York, NY, Taylor and Francis Group, LLC. Burns, J. M. (1978). Transformational Leadership Theory, New York, Harper and Row Publishers.

Bogler, R. (2015). The Influence of Leadership Style on Teacher Job Satisfaction. Educational Quarterly, 37, 662-683.

Cacioppe, R. (1998). An integrated model and approach for the design of effective leadership development programs Leadership and Organization Development Journal, 19 44-53.

Cascio, W. F. (2000). Managing a virtual workplace. Academy of Management Eecutive, 14 (3), 81-90.

Chen, J.K.C. \& Sriphon, T. (2021). Persiperctive on COVID-19 Pandemic Facors Impacting Organizational Leadership. Sustainability 2021 13, 320. https://doi.org/10.3390/su 130 63230

Cho, J., \& Dansereau, F. (2010). Are transformational leaders fair? A multi-level study oftransformational leadership, justice perceptions, and organizational citizenship behaviours The Leadership Quarterly 21, 409-421.

Chowdhury, R. G. (2014). A study on the impact of leadership styles on employee motivation and commitment: An empirical study of selected organisations in corporate sector. Doctor of Philosophy in Business Management, Patil University.

Conger, J. A., \& Kanungo, R. N. (1998). Charismatic leadership in organizations: Perceivedbehavioural attributes and their measurement Journal of Organizational Behaviour, 15, 439-452.

Edmonds, W. A., \& Kennedy, T. D. (2016). An applied guide to research designs: Quantitative, qualitative, and mixed methods, Sage Publications.

Emmeett, J., Schrah, G., Schrimper, M., \& Wood. (2020). A COVID- 19 and Employee Experianc: How Leaders can Seize the momment. Available on 
line:https.//www.mckinsey.com/business-functions/organizations/ourinsights/covid19.

Faul, F., Erdfelder, E., Lang, A. G., \& Buchner, A. (2014). Addictive Behaviours. Journal of European Psychological Science 391430 -1433.

Fredendall, L., Laohavichien, T., \& Cantrell, R. (2009). The effects of transformational and transactional leadership on quality improvement. The Quality Management Journal, 16, 7-24.

Gazor, H. (2012). A Literature Review on Challenges of Virtual Team's Leadership. Journal of Sociological Research, 3(2), 134-145.

Goodnight, R. (2011). Laissez-Faire Leadership. Encyclopedia of Leadership London, UK, Sage Publications.

Hrebiniak, L. G. (1974). 'Effects of job level and participation on employee attitudes and perception of influence'. Academy of Management Journal, 17. 649-662.

Jeremy, M., Melinde, C., \& Ciller, V. (2012). Perceived leadership style and employee participation in a manufacturing company in the democratic republic of Congo, African journal of business management, 6(15), 5389-5398.

Lam, C. S., \& O'higgins, E. (2012). Enhancing employee outcomes: The interrelated Influences of managers' emotional intelligence and leadership style. Leadership and Organization Development Journal, 33, 149-174.

Lewis, C. W., Gilman, S. C. (2013). The Ethics Challenge in Public Service: A Problem-solving Guide. JosseyBass, San Francisco, CA.

Lassey, W. (1976). Leadership and social change, California, University Associates.

Lussier, R. N., \& Achua, C. F. (2007). Management Fundamentals: Concepts, Application, Skill Development. $3^{\text {rd }}$ ed. Cincinat: South Western Publishing.

Mawoli, M., \& Mohammed H. \& Sarkin-Daji L. (2017). Effect of Leadership Styles on Employees' Job Performance: Evidence from Federal Medical Centre in Niger State. Lapai Journal of Management Science, 4, 2838.

Mehtab, K., Rehman, A. U., Ishfaq, S., \& Jamil, R. A. (2017). Virtual MSG Management Study Guide. (n.d.). Retrieved from https://www.managementstudyguide.com/managingsocial-isolation-in-virtualteams.htm

Mowday, R., Porter, L., \& Steers, R. M. (1982). Employee-Organization Linkages: The Psychology of Commitment, Absenteeism, and Turnover. New York: Academic Press'

Murphy, S. A., \& Drodge, E. N. (2004). The four I's of police leadership: A case study heuristic. International Journal of Police Science \& Management, 6, 1-15.

Muterera, J. (2012). Leadership Behaviours and their Impact on Organizational Performance in Governmental Entities International Journal of Sustainable Development 19-24.

Mwenje, J., \& Mwenje, E. (2017). Leadershipstylesin organizationsduring harsheconomicenvironments. African Journal of Business Management.

Northouse, P. G. (2016). Leadership: Theory and practice, Sage publications.

Obiwuru, T. C. (2011). Effect of Leadership Style on Organizational Performance: A Survey Of Selected Small Scale Enterprises in Ikosi-Ketu Council Development Area of Lagos State, Nigeria. Australian Journal of Business and Management Research, 1, , 1-20.

Oladipo, K., Jamilah, O., Abduldaud, S., Jeffery, L., \& Salami, D. (2016). Review of leadership theories and Organizational performances. International Business Management Journal, 7, 50-54.

Ololube, N. P. (2013). Educational Management, Planning and Supervision: Model for Effective Implementation, Owerri, SpringField Publishers. 
Powell, A., Piccoli, G., and Ives, B. (2004). 'Virtual Teams: A Review of Current Literature and Directions for Future Research', The Databas for Advances in Information Systems, vol. 35, no. 1.

Rejas, L. P., Almonte, M. D., \& Ponce, J. R. (2006). Transformational and Transactional Leadership. A Study of their Influence in Small Companies Ingenerate. Revista Chilena De Ingeria, 14, 156-166.

Richard, L., Robert, C., Ginnett, G. J. C. (2009). Leadership: Enhancing the Lessons of Experience, McGraw-Hill Irwin.

Rist, K. (2020). Workingfrom home: The New'Industrial'Revolution. Forbes. https://www.forbes.com/sites/kjartanrist/2020/09/07/working-from-home-the-newindustrialrevolution/?sh=72332d4a62fd

Shah, M., \& Kamal, H. (2015).Transactional Leadershipand job Performance: an Empirical Investigation. Institute of Business Administration, 2, 69-81.

Skogstad, A., Einarsen, S., Torsheim, T., Aasland, M. S., \& Hetland, H. (2007). The Destructiveness of LaissezFaire Leadership Behaviour. Journal of Occupational Health Psychology, 12, 80-92.

Shuttleworth, M. (2015). Internal Consistency - reliability. [Online]. Available: https:// explorable.com/internal

[Accessed 27 January 2020].

Tsigu, G. T., \& Rao, D. P. (2015). Leadership styles: their impact on job outcomes in Ethiopian banking industry.ZENITH International Journal of Business Economics \& Management Research, 5, 41-52.

Veliu, L. (2017).The influence of Leadership Styles on Employee Performance. Journal of Management, 31 (2), 60-69

Wolor, C. W., Solikhah, S., Fidhyallah, N. F., \& Lestari, D. P. (2020). Effectiveness of E-Training, e-Leadership, and Work Life Balance on Employee Performance during COVID- 19. The journal of Asian Finance. Economics and Business.

Wong, S. I., \& Giessner, S. R. (2018). The thin line between empowering and laissez-faire leadership: An expectancy-match perspective. Journal of Management, 44, 757-783. Yamane, T. 1967. Elementary sampling theory.

Yousef, D. A. (2000). Organizational commitment: a mediator of the relationships of leadership behaviour with job satisfaction and performance in a non-westerncountry. Journal of managerial Psychology, 15, 6-24. 